einstein

Official Publication of the Instituto Israelita

de Ensino e Pesquisa Albert Einstein

ISSN: 1679-4508 | e-ISSN: 2317-6385
How to cite this article:

Chade MC, Piato S, Galvão MA, Aldrighi

JM, Negrini R, Mateus EF, et al. Evaluation

of survivin immunoexpression in the

differentiation of high- and low-grade

breast ductal carcinoma in situ.

einstein (São Paulo). 2018;16(1):eA04065.

Corresponding author:

Milca Cezar Chade

Rua Dr. Cesário Motta Júnior, 61

$3^{\text {rd }}$ floor - Vila Buarque

Zip code: 01221-020 - São Paulo, SP, Brazil

Phone: (55 11) 3367-7870

E-mail: milcacmc@gmail.com

Received on:

Apr 25, 2017

Accepted on:

Aug 22, 2017

Conflict of interest:

none.

Copyright 2018

(c) BY

This content is licensed

under a Creative Commons

Attribution 4.0 International License.
ORIGINAL ARTICLE

\section{Evaluation of survivin immunoexpression in the differentiation of high- and low-grade breast ductal carcinoma in situ}

\author{
Expressão da proteína survivina em carcinoma ductal in situ \\ de mama de alto e de baixo grau
}

\author{
Milca Cezar Chade', Sebastião Piato', Maria Antonieta Longo Galvão', José Mendes Aldrighi', \\ Rômulo Negrini', Evandro Falaci Mateus', Enio Martins Medeiros² \\ ' Faculdade de Ciências Médicas, Santa Casa de São Paulo, São Paulo, SP, Brazil. \\ 2 Hospital Israelita Albert Einstein, São Paulo, SP, Brazil.
}

DOI: $10.1590 /$ S1679-45082018A04065

\section{$\triangle$ ABSTRACT}

Objective: To evaluate the expression of survivin protein in low- and high-grade ductal carcinoma in situ. Methods: Breast tissue fragments obtained by incisional biopsy and surgical procedures of 37 women with ductal carcinoma in situ of the breast were subdivided into two groups: Group A, composed of women with low-grade ductal carcinoma in situ, and Group B, women with high-grade ductal carcinoma in situ. Survivin protein expression test was performed by immunohistochemistry, using a monoclonal antibody clone I2C4. The criterion to evaluate survivin immunoexpression was based on the percentage of neoplastic cells that presented brown-gold staining. This criterion was positive when the percentage of stained cells was $\geq 10 \%$. Results: The survivin protein was expressed in 22 out of 24 cases of high-grade ductal carcinoma in situ $(78 \%)$, whereas, in Group A, of low-grade ductal carcinoma in situ $(n=13)$, it was positive in only 6 cases $(21.40 \% ; p=0.004)$. Conclusion: The frequency of expression of survivin was significantly higher in the group of patients with high-grade ductal carcinoma in situ compared to those in the low-grade ductal carcinoma in situ group.

Keywords: Inhibitor of apoptosis proteins; Carcinoma, intraductal, noninfiltrating; Biomarkers, tumor; Neoplasm proteins; Breast neoplasms

\section{RESUMO}

Objetivo: Avaliar a imunoexpressão da proteína survivina nos carcinomas ductais in situ de mama de baixo e de alto graus. Métodos: Fragmentos de tecido mamários obtidos por biópsia incisional e procedimentos cirúrgicos de 37 mulheres acometidas por carcinoma ductal in situ de mama foram subdivididos em dois grupos: Grupo A, formado por mulheres com carcinoma ductal in situ de baixo grau; e Grupo $B$, por mulheres com carcinoma ductal in situ de alto grau. A pesquisa de expressão da proteína survivina foi realizada pela técnica de imuno-histoquímica, utilizando-se anticorpo monoclonal clone I2C4. 0 critério de avaliação da imunoexpressão da survivina baseou-se na percentagem de células neoplásicas que apresentava coloração castanho-dourada. Considerouse tal critério positivo quando a percentagem de células apresentasse marcação $\geq 10 \%$. Resultados: A proteína survivina apresentou-se expressa em 22 dos 24 casos de carcinoma ductal in situ de alto grau (78\%), enquanto no Grupo $A$, de carcinoma ductal in situ de baixo grau $(n=13)$, apresentou-se positiva em apenas 6 casos (21,40\%; $p=0,004)$. Conclusão: 0 índice de frequência de expressão da survivina foi significativamente mais elevado no grupo de pacientes com carcinoma ductal in situ de alto grau, quando comparado às do grupo com carcinoma ductal in situ de baixo grau.

Descritores: Proteínas inibidoras de apoptose; Carcinoma intraductal não infiltrante; Biomarcadores tumorais; Proteínas de neoplasias; Neoplasias da mama 


\section{INTRODUCTION}

Breast cancer is the second most frequent type of neoplasm among women, ${ }^{(1)}$ representing approximately $22 \%$ of new cases diagnosed every year. In 2016, breast cancer incidence in the United States was of 231,840 cases, and 60,290 (21.7\%) were diagnosed as ductal carcinoma in situ (DCIS). ${ }^{(2)}$ In some series of non-palpable tumors, detected by mammography in screening programs, up to $45 \%$ of cases were DCIS. $^{(3-5)}$

It is noteworthy that, when left untreated, DCIS poses a risk between 30 and $50 \%$ of progressing to invasive carcinoma within 10 years. ${ }^{(6,7)}$ However, it is not yet clear which forms of DCIS lesions progress to an invasive disease or have an indolent development.

A better molecular and histopathological DCIS characterization can bring additional information to evaluate the prognosis of the disease, and allows customizing an appropriate treatment for each patient. There have been advancements in molecular studies for the assessment of risk and progression of premalignant diseases; however, they are still quite modest in clinical practice. ${ }^{(6-8)}$

There is evidence that the activity mentioned is significantly more marked in DCIS lesions than in invasive carcinoma. ${ }^{(9)}$ When comparing DCIS, lowgrade lesions present higher cell apoptosis rate than high-grade. ${ }^{(9)}$

Considering survivin protein has important antiapoptotic properties, some researchers have conducted studies to correlate its expression to aggressiveness of breast cancer. ${ }^{(10-15)}$

The antiapoptotic action of survivin can occur through the direct inhibition of effector caspases 3 and 7 and of initiator caspase 9 , which play a relevant role in the mechanism of programmed cell death. ${ }^{(16)}$ Another survivin antiapoptotic action consists of antagonizing the activity of the second mitochondria-derived activator of caspase/direct inhibitor of apoptosisbinding protein with low pI (Smac/DIABLO). This protein, released from the mitochondria, binds to and removes inhibitors of apoptosis protein (IAP) from its inhibitory binds to caspases, thus promoting apoptosis. Thus, survivin, by inhibiting caspase activation, would increase cell survival, both directly and/or via Smac/ DIABLO. ${ }^{(16)}$

Regarding the expression of survivin protein in neoplastic cells, Youssef et al., ${ }^{(17)}$ observed an inverse correlation with the size of the primary tumor; in addition, the expression of estrogen and progesterone receptors is directly proportional to size of neoplasm and survivin expression. Similarly, other clinical trials demonstrated that survivin is associated to a poor prognosis and lower rates of disease-free survival. ${ }^{(15,18)}$

Some retrospective studies on breast cancer showed that survivin protein is an important marker of cancer aggressiveness and poor prognosis, leading to decreased overall survival. ${ }^{(19,20)}$ The studies on messenger RNA (mRNA) microarray are consistent with these results, also identifying survivin as a risk factor associated to breast cancer. ${ }^{(21,22)}$

In a study about the correlation between survivin expression and prognosis, conducted with 167 women with breast cancer stages I, II, and II, Tanaka et al., ${ }^{(23)}$ found survivin expression in 70\% (118) of tumors. They saw that survivin expression was the most consistent prognostic factor in comparison to other clinicopathological prognostic characteristics, including tumor size, clinical stage, lymphatic involvement, hormone receptors and histological type.

In an investigation published in 2007, Yamashita et al., ${ }^{(10)}$ reported survivin is an indicator of recurrence risk for early stage breast cancer. In 2008, Okumura et al., ${ }^{(24)}$ published the results of a study about survivin expression, which included 52 cases of pure DCIS and 28 cases of DCIS with foci of microinvasion (DCIS-MI), and showed expression of this protein was significantly higher in the DCIS-MI cases than in those with a sample of only DCIS.

A comparative study conducted in Brazil found a significantly higher expression of survivin in specimens of triple-negative breast carcinoma, which is generally highly aggressive, than in specimens of luminal A breast carcinoma, which is notably known as less aggresive. (25)

\section{OBJECTIVE}

To evaluate survivin protein expression in low-grade and high-grade breast ductal carcinoma in situ.

\section{METHODS}

For this study, we selected 37 fragments of surgical specimens or biopsy material from patients with breast DCIS. All patients were treated in the Mastology Sector - 
Department of Gynecology and Obstetrics, between 2014 and 2016. Only samples with low-and high-grade DCIS were selected, with no associated invasive lesions and no previous treatment.

The study was previously approved by the hospital Research Ethics Committee for complying with ethical principles, Resolution 466/96 from the National Health Council/Ministry of Health, and with additional internal norms, under protocol number 1674151, CAAE: 57764416.4.0000.5479.

The specimens were classified as Groups A and B, according to the results of histopathological exams carried out at the Department of Pathology. Group A included 13 cases of low-grade DCIS, and Group B had 24 cases of high-grade DCIS.

Specimen selection for both groups included the following exclusion criteria: association of neoplasm and pregnancy and nursing; previous chemotherapy, hormone therapy or radiation therapy; and inappropriate material.

To confirm the diagnosis of both forms of DCIS, the same examiner reviewed the histological exams. Intermediate-grade DCIS cases were also excluded.

Initially, each fragment was embedded in a paraffin block. From each block, a $4 \mu \mathrm{m}$ thick histological section was obtained using a rotating microtome. The sections were stained with hematoxylin-eosin (HE), and assessed by light optical microscopy. Characterization of histological types as high- and low-grade DCIS was done according to guidelines of the Brazilian Society of Pathology. Survivin protein expression was analyzed by immunohistochemistry, in $4 \mu \mathrm{m}$ thick sections, using a lyophilized anti-human mouse monoclonal antibody, clone I2C4, IgG2a Kappa immunoglobulinisotype class. Each kit contained $1 \mathrm{~mL}$ and was diluted to $1 / 50$. The $\mathrm{pH}$ was 6.0 , and recovery was done through microwaves and an incubation period of 15 minutes.

Survivin immunoexpression through breast DCIS epithelial cells occurs in the nuclei and in the cytoplasm, as shown in figure 1.

As per the manufacturer's recommendations, to evaluate survivin immunoexpression, we used, as a positive control, samples of prostate tissue fragments, in which the brownish gold stains are intense in the nucleus and cytoplasm. In figure $2 \mathrm{~A}$, we can see a histological section of prostate tumor with negative control; and in figure $2 \mathrm{~B}$, we find a positive control.

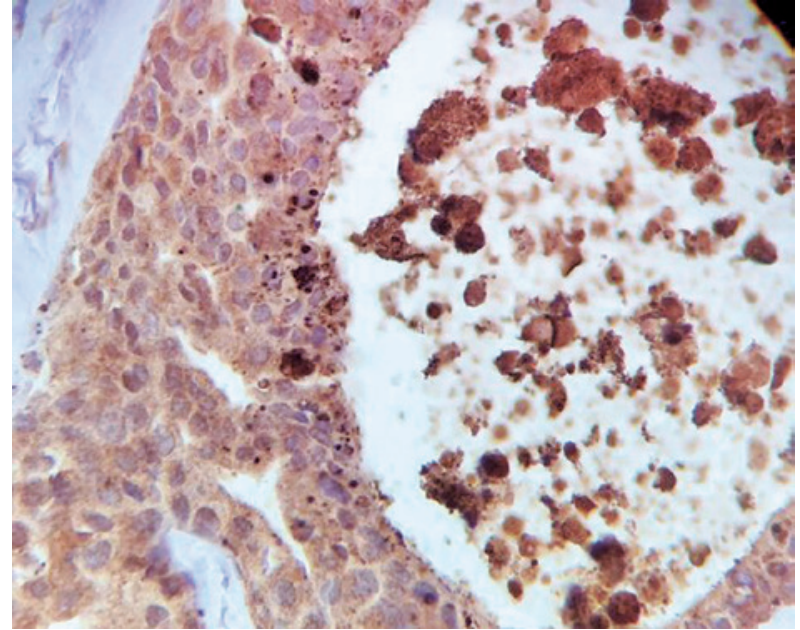

Figure 1. Breast ductal carcinoma in situ cell nuclei and cytoplasm stained brownish gold by antisurvivin antibody (400x)

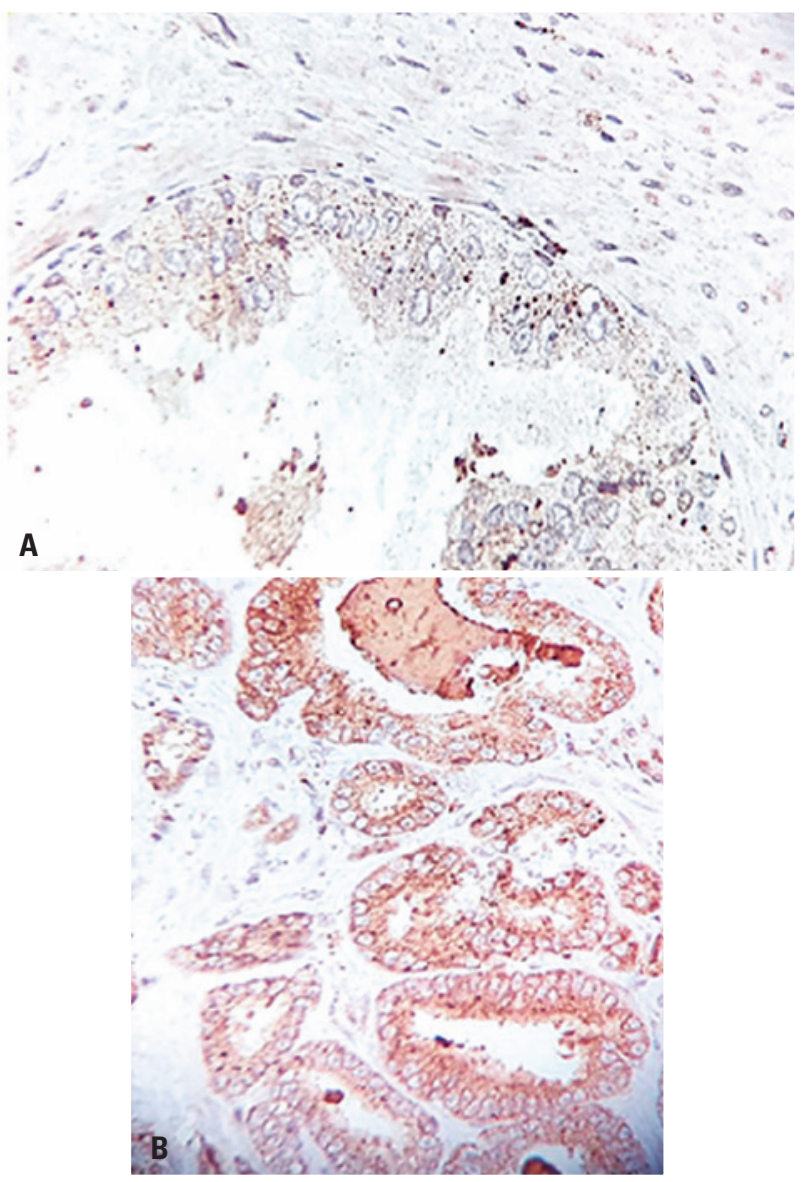

Figure 2. (A) Prostate tumor sample considered as negative control for anti-survivin reaction (400x). (B) Prostate tumor sample considered as positive control for antisurvivin reaction (400x) 
Immunohistochemical reactions were assessed by two independent evaluators using a Nikon Eclipse E400 microscope with two binocular heads.

The evaluation criteria for survivin expression was based on the percentage of neoplastic cells that presented a brownish gold staining in the nucleus or cytoplasm. The criterion was considered positive when $\geq 10 \%$ of sample cells were stained. ${ }^{(25)}$

To further stratify the positivity and negativity grades of samples marked by the antisurvivin antibody, these samples was subdivided as follows (Table1).

In all slides considered positive, nucleus and cytoplasm were equally positive.

Figure 3 shows a histological section of DCIS tissue samples considered negative for antisurvivin reaction, and figure 4 shows a premalignant tissue histological section considered positive.

Table 1. Positivity and negativity grade stratification of samples marked by survivin

\begin{tabular}{lc}
\hline \multicolumn{2}{c}{ Survivin } \\
\hline Negative $-\mathbf{0}$ & Positive $-\mathbf{2}$ \\
\hline 0 and 1 if $\leq 10 \%$ & 2 and 3 if $>10 \%$ \\
\hline
\end{tabular}

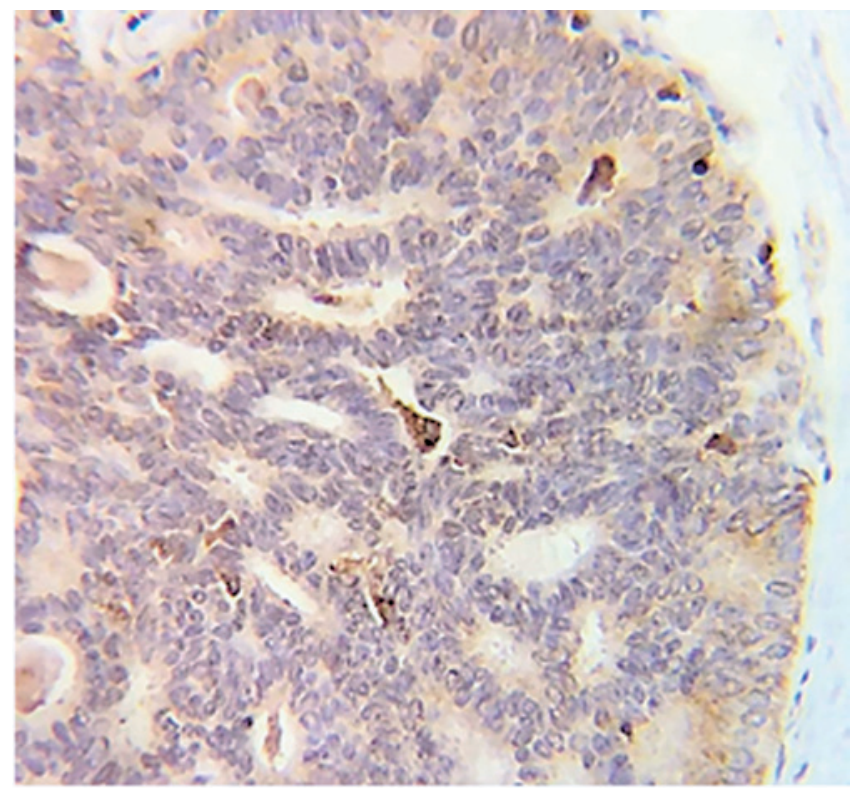

Figure 3. Sample of ductal carcinoma in situ considered negative for anti-survivin reaction $(400 x)$

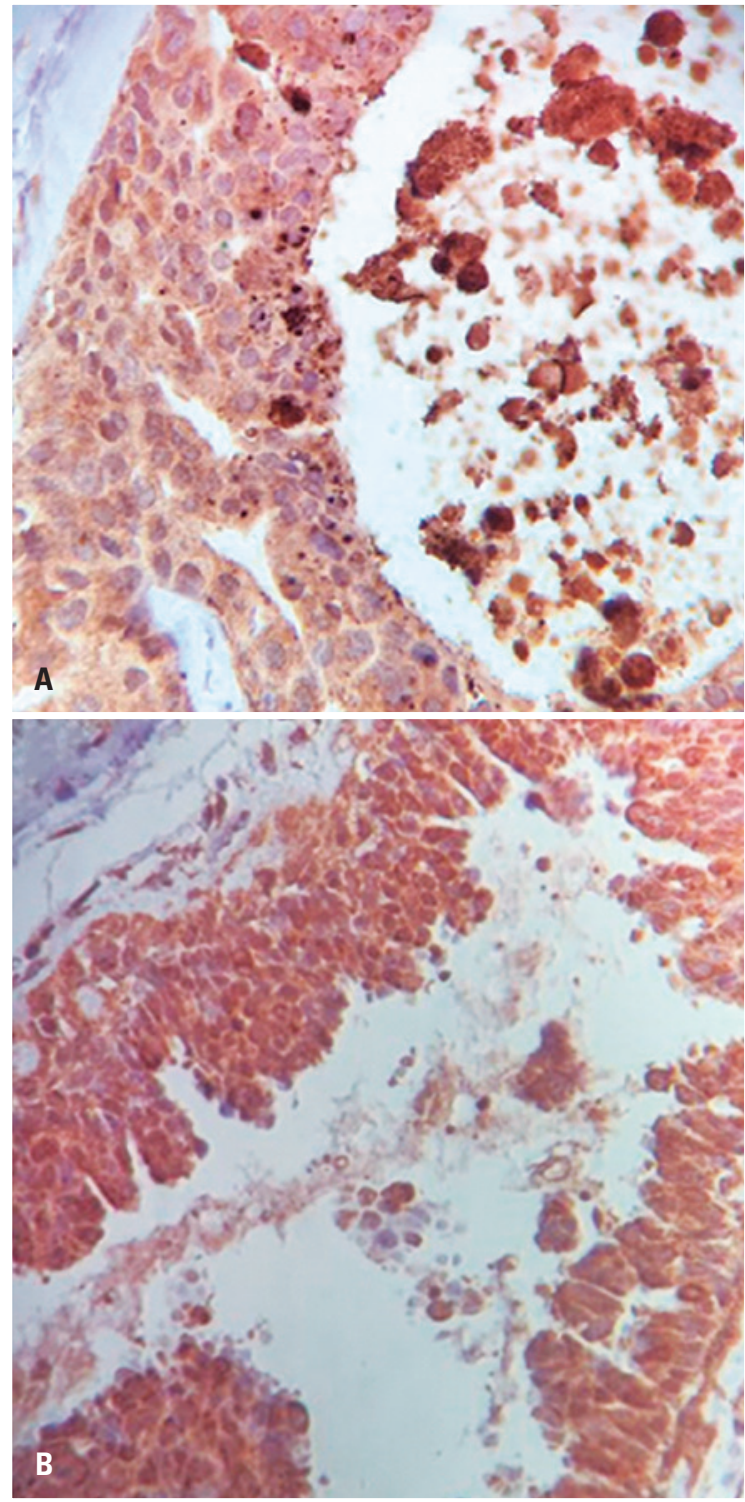

Figure 4. (A) Sample of high-grade ductal carcinoma in situ (with comedonecrosis) considered positive for anti-survivin reaction. (B) Sample of high-grade ductal carcinoma in situ considered positive for anti-survivin reaction $(400 \mathrm{x})$.

\section{Statistical analysis}

For the association between the variable survivin and Groups A and B, we applied Fisher's exact test. Significance level was set at 5\% (0.050) for statistical tests. A statistically significant difference was characterized when the calculated significance value (p) was $<5 \%$ (0.05). A calculated significance value $(\mathrm{p}) \geq 5 \%(0.050)$ indicated a non-statistically significant difference or relation. We also used a likelihood ratio test to assess data stratification.

An MS-Excel electronic spreadsheet, version MS-Office 2013, was used to organize the data, and the 
IBM Statistical Package for the Social Sciences (SPSS), version 23.0 was used to obtain the results.

\section{RESULTS}

Survivin protein was positive in 22 out of 24 high-grade DCIS cases $(78.6 \%)$, whereas in the group of 13 low-grade DCIS cases, survivin was positive in 6 of them $(21.4 \%)$. In $77.8 \%$ of cases survivin was negative, and DCIS was low-grade (Table 2).

Table 2. Comparison of survivin positive and negative expression in high- and low-grade ductal carcinoma in situ

\begin{tabular}{lcc}
\hline \multirow{2}{*}{ Survivin (positive-negative) } & \multicolumn{2}{c}{ Nuclear grade classification $\mathbf{n}(\%)$} \\
\cline { 2 - 3 } & High & Low \\
\hline Positive & $6(21.40)$ & $22(78.60)$ \\
Negative & $7(77.80)$ & $2(22.20)$ \\
\hline
\end{tabular}

Fisher's exact test: $p=0.004$.

The statistical analysis showed a significantly elevated survivin expression in high-grade DCIS as compared to low-grade lesions $(\mathrm{p}=0.004)$.

When comparing survivin positive and negative expression, subdivided into zero, 1, 2, and 3 in Groups $\mathrm{A}$ and $\mathrm{B}$, we applied the likelihood ratio test to verify a possible difference between the four categories of the variable survivin for the variable nuclear grade classification.

The results in table 3 show that survivin expression was significantly more elevated in high-grade DCIS as compared to low-grade DCIS, when classifying the positivity grade $(p=0.001)$. Among the lesions with negative expression, those classified as zero were low-grade in $100 \%$ of cases; whereas those classified as 1 were observed in $60 \%$. And the high-grade lesions, classified as 3 , were strongly positive in $84 \%$ of cases.

Table 3. Comparison between survivin positive and negative expression, subdivided into zero, 1, 2 and 3, in high- and low-grade ductal carcinoma in situ

\begin{tabular}{lcc}
\hline \multirow{2}{*}{ Survivin } & \multicolumn{2}{c}{ Nuclear grade classification $\mathbf{n}(\%)$} \\
\cline { 2 - 3 } & Low & High \\
\hline 0 negative & $4(100)$ & 0 \\
1 negative & $3(60.00)$ & $2(40.00)$ \\
2 positive & $2(66.70)$ & $1(33.30)$ \\
3 positive & $4(16.00)$ & $21(84.00)$ \\
\hline
\end{tabular}

Fisher's exact test: $p=0.001$

\section{DISCUSSION}

Proposals about the procedures used in breast DCIS treatment greatly vary, ranging from insufficient to excessive. To reach a consensus regarding the appropriate treatment for low- and high-grade DCIS, several studies related to predictive factors have been developed.

The classic prognostic factors of breast DCIS do not accurately predict local recurrence. The discovery of molecular biomarkers has played an important role in prognosis and decisions about treatment, including conservative therapies, mastectomy, radiation and hormone therapy. However, it is thought that the use of biomarkers is not enough to establish an ideal DCIS management. Therefore, a new predictive strategy has been recently proposed, which consists of a DCIS recurrence and prognosis score, as a modified Oncotype Dx (Genomic Health, Redwood City, CA, USA). This proposal undoubtedly offers advancements that will allow an even better patient selection, especially for adjuvant therapies, making way for a individualized treatment plan. ${ }^{(26)}$

Davis et al., ${ }^{(27)}$ analyzed a biomarker panel (estrogen receptor, HER-2, Ki67, p53, cyclin D1, COX-2, caveolin-1, survivin, and PPAR-g) and a DCIS clinical and histological factor panel to determine associations with recurrence of disease. The variables analyzed in the study with 70 patients were age, tumor size, margin, grades of in situ tumors, presence of necrosis, and histological type.

The proponents of the abovementioned score included in their algorithm the survivin gene, among other neoplasm-related genes, considering many studies that highlighted the role of survivin in carcinomas from different organs, including breast, ${ }^{(8,23)}$ regarding carcinogenesis, prognosis and survival.

There are few investigations about survivin protein, despite the evidence of its relevant role in breast carcinogenesis and several studies recognizing it is an effective prognostic and disease-free survival marker. Scarce research is particularly noticeable regarding the lesion that precedes invasive breast cancer, i.e., DCIS. We believe this is very relevant considering survivin may allow a target therapy based on its inhibitory action.

In a study published in 2012 that included lymphoblastic leukemia patients, Tyner et al.,(28) observed that sepantronium bromide (YM-155) was able to inhibit survivin action, thus reducing lymphoblast activity. Kumar et al., ${ }^{(29)}$ found YM-155 reverted cisplatin resistance in patients with head and neck carcinoma, making chemotherapy more effective. In a prospective study with multiple myeloma patients, de Haart et al., ${ }^{(30)}$ 
observed a prolonged remission of the disease with the use of YM-155.

\section{CONCLUSION}

Survivin protein immunoexpression was significantly more elevated in epithelial cells of high-grade breast ductal carcinoma in situ as compared to low-grade lesions. There was a significant correlation between survivin immunoexpression and the differentiation between lowand high-grade ductal carcinoma in situ. We believe the results from this study, despite its relatively small sample, contribute to the current effort to develop new tools to improve the objective grade differentiation in ductal carcinoma in situ, leading to better management of ductal carcinoma in situ of the breast.

\section{REFERENCES}

1. Frasson $A L$, Garcia GN, Millen $E$, Zerwes FP, Brenelli $F$, Urban $C$, et al. Carcinoma Ductal in situ. In: Millen E, Frasson A, Novita G, editor. Doenças da Mama. Guia de bolso baseado em evidências. São Paulo: Atheneu; 2013. p. $151-6$

2. Instituto Nacional de Câncer José Alencar Gomes da Silva (INCA). Coordenação de Prevenção e Vigilância. Estimativa 2016: Incidência de Câncer no Brasil [Internet]. Rio de Janeiro: INCA; 2016 [citado 2017 Ago 18]. Disponível em: http:// www.inca.gov.br/estimativa/2016

3. Collins LC, Laronga C, Wong JS. Breast ductal carcinoma in situ: Epidemiology, clinical manifestations, and diagnosis [Internet]. UpToDate; 2017 [cited 2017 Aug 17]. Available from: https://www.uptodate.com/contents/breastductal-carcinoma-in-situ-epidemiology-clinical-manifestations-anddiagnosis? search = breast-ductalcarcinoma-in-situ-epidemiology-clinicalmanifestations-and-\&source $=$ search_result\&selectedTitle $=1 \sim 150 \&$ usag e_type $=$ defaultødisplay_rank $=1$

4. Goldhirsch A, Wood WC, Coates AS, Gelber RD, Thürlimann B, Senn HJ: Panel members. Strategies for subtypes--dealing with the diversity of breast cancer: highlights of the St. Gallen International Expert Consensus on the Primary Therapy of Early Breast Cancer 2011. Ann Oncol. 2011;22(8):1736-47.

5. Collins LC, Laronga C, Wong JS. Ductal carcinoma in situ: treatment and prognosis [Internet]. UpToDate; 2018 [cited 2017 Aug 17]. Available from: https://www.uptodate.com/contents/ductal-carcinoma-in-situ-treatment-and-

6. Mardekian SK, Bombonati A, Palazzo JP. Ductal carcinoma in situ of the breast: the importance of morphologic and molecular interactions. Hum Pathol. 2016;49:114-23. Review.

7. Siziopikou KP. Ductal carcinoma in situ of the breast: current concepts and future directions. Arch Pathol Lab Med. 2013;137(4):462-6. Review.

8. Kawasaki H, Altieri DC, Lu CD, Toyoda M, Tenjo T, Tanigawa N. Inhibition of apoptosis by survivin predicts shorter survival rates in colorectal cancer. Cancer Res. 1998;58(22):5071-4.

9. Okada H, Mak TW. Pathways of apoptotic and non-apoptotic death in tumor cells. Nat Rev Cancer. 2004;4(8):592-603. Review.

10. Yamashita S, Masuda Y, Kurizaki T, Haga Y, Murayama T, Ikei S, et al. Survivin expression predicts early recurrence in early-stage breast cancer. Anticancer Res. 2007;27(4C):2803-8.
11. Hinnis AR, Luckett JC, Walker RA. Survivin is an independent predictor of short-term survival in poor prognostic breast cancer patients. Br J Cancer 2007:96(4):639-45.

12. Athanassiadou AM, Patsouris E, Tsipis A, Gonidi M, Athanassiadou P. The significance of survivin and nectin-4 expression in the prognosis of breast carcinoma. Folia Histochem Cytobiol. 2011;49(1):26-33.

13. Ambrosini G, Adida C, Sirugo G, Altieri DC. Induction of apoptosis and inhibition of cell proliferation by survivin gene targeting. J Biol Chem. 1998;273(18):11177-82.

14. Altieri DC. Survivin, versatile modulation of cell division and apoptosis in cancer. Oncogene. 2003;22(53):8581-9. Review.

15. Coumar MS, Tsai FY, Kanwar JR, Sarvagalla S, Cheung CH. Treat cancers by targeting survivin: just a dream or future reality? Cancer Treat Rev. 2013; 39(7):802-1. Review.

16. Li F, Brattain MG. Role of the Survivin gene in pathophysiology. Am J Pathol. 2006;169(1):1-11. Review.

17. Youssef NS, Hewedi LH, Abd Raboh NM. Immunohistochemical expression of survivin in breast carcinoma: relationship with clinicopathological parameters, proliferation and molecular classification. J Egypt Natl Canc Inst. 2008;20(4): 348-57.

18. Son BH, Choi JS, Lee JH. Prognostic values of KAl1 and survivin expression in an infiltrating ductal carcinoma of the breast. Pathology. 2005;37(2):131-6. Erratum in: Pathology. 2005;37(4):331.

19. Martins AN. Resposta clínica do carcinoma ductal de mama localmente avançado à quimioterapia neoadjuvante com antracíclicos, consoante a expressão da proteína survivina nas células do tumor [tese]. São Paulo: Faculdade de Ciências Médicas da Santa Casa de São Paulo; 2010.

20. Rexhepaj E, Jirstrom K, O'Connor DP, O'Brien SL, Landberg G, Duffy MJ, et al. Validation of cytoplasmic-to-nuclear ratio of survivin as an indicator of improved prognosis in breast cancer. BMC Cancer. 2010;10(1):639.

21. Lee CW, Simin K, Liu O, Plescia J, Guha M, Khan A, et al. A functional notchsurvivin gene signature in basal breast cancer. Breast Cancer Res. 2008;10(6):R97.

22. Yamanaka K, Nakata M, Kaneko N, Fushiki H, Kita A, Nakahara T, et al. YM155, a selective survivin suppressant, inhibits tumor spread and prolongs survival in a spontaneous metastatic model of human triple negative breast cancer. Int J Oncol. 2011;39(3):569-75.

23. Tanaka K, Iwamoto S, Gon, G, Nohara T, Iwamoto M, Tanigawa N. Expression of survivin and its relationship to loss of apoptosis in breast carcinomas. Clin Cancer Res. 2000;6(1):127-34.

24. Okumura $Y$, Yamamoto $Y$, Zhang Z, Toyama T, Kawasoe $T$, Ibusuki $M$, et al. Identification of biomarkers in ductal carcinoma in situ of the breast with microinvasion. BMC Cancer. 2008;8:287.

25. Martins AN. Expressão da proteína survivina nos subtipos triplo negativo e luminal a do carcinoma do tipo não especial de mama [tese]. São Paulo: Faculdade de Ciências Médicas da Santa Casa de São Paulo; 2014.

26. Solin LJ, Gray R, Baehner FL, Butler SM, Hughes LL, Yoshizawa C, et al. A multigene expression assay to predict local recurrence risk for ductal carcinoma In situ of the breast. J Natl Cancer Inst. 2013;105(10):701-10.

27. Davis JE, Nemesure B, Mehmood S, Nayi V, Burke S, Brzostek SR, et al. Her2 and Ki67 biomarkers predict recurrence of ductal carcinoma in situ. Appl Immunohistochem Mol Morphol. 2016;24(1):20-5.

28. Tyner JW, Jemal AM, Thayer M, Druker BJ, Chang BH. Targeting survivin and p53 in pediatric acute lymphoblastic leukemia. Leukemia. 2012;26(4):623-32.

29. Kumar B, Yadav A, Lang JC, Cipolla MJ, Schmitt AC, Arradaza N, et al. YM155 reverses cisplatin resistance in head and neck cancer by decreasing cytoplasmic survivin levels. Molec Cancer Ther. 2012;11(9):1988-98.

30. de Haart SJ, van de Donk NW, Minnema MC, Huang JH, Aarts-Riemens T, Bovenschen $\mathrm{N}$, et al. Accessory cells of the microenvironment protect multiple myeloma from T-cell cytotoxicity through cell adhesion-mediated immune resistance. Clin Cancer Res. 2013;19(20):5591-601. 